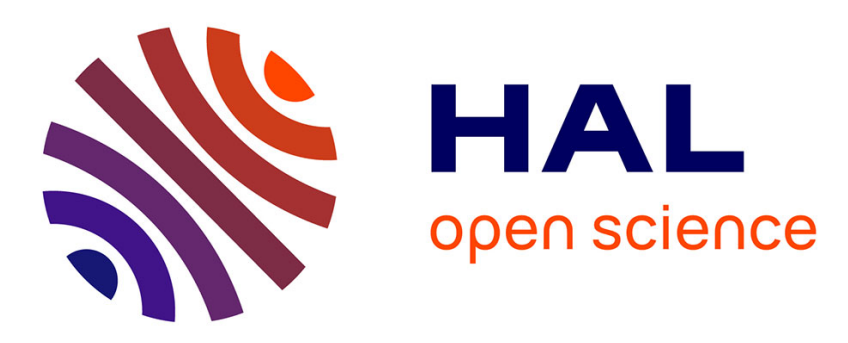

\title{
Future Home 4.0 for People with Major Neurodegenerative Disorders, Finding the Contradictions
}

Jean Renaud, Rémy Houssin, Negar Armaghan, Mickaël Gardoni

\section{- To cite this version:}

Jean Renaud, Rémy Houssin, Negar Armaghan, Mickaël Gardoni. Future Home 4.0 for People with Major Neurodegenerative Disorders, Finding the Contradictions. 19th International TRIZ Future Conference (TFC), Oct 2019, Marrakesh, Morocco. pp.417-426, 10.1007/978-3-030-32497-1_33 . hal02905563

\section{HAL Id: hal-02905563 \\ https://hal.inria.fr/hal-02905563}

Submitted on 23 Jul 2020

HAL is a multi-disciplinary open access archive for the deposit and dissemination of scientific research documents, whether they are published or not. The documents may come from teaching and research institutions in France or abroad, or from public or private research centers.
L'archive ouverte pluridisciplinaire HAL, est destinée au dépôt et à la diffusion de documents scientifiques de niveau recherche, publiés ou non, émanant des établissements d'enseignement et de recherche français ou étrangers, des laboratoires publics ou privés.

\section{(c)(1)}

Distributed under a Creative Commons Attribution| 4.0 International License 


\title{
Future Home 4.0 for People with Major Neurodegenera- tive Disorders, Finding the Contradictions
}

\author{
Jean Renaud ${ }^{1,2}$, Rémy Houssin ${ }^{1}$, Negar Armaghan ${ }^{3}$, Mickaël Gardoni² \\ ${ }^{1}$ ICube, UMR-7357, Strasbourg 67, France, jean.renaud@insa-strasbourg.fr \\ ${ }^{2}$ ÉTS, 1100, rue Notre-Dame Ouest, Montréal (QC) Canada \\ ${ }^{3}$ Department of Technology Development Studies, Iranian Research Organization for Science \\ and Technology, P.O. Box 33535-11, Tehran, Iran, armaghan@irost.org
}

\begin{abstract}
With the aging of the population, old people increasingly wish to stay at home before entering to a retirement home. There are several reasons such as: the cost of entry, the impersonal side and the lack of solicitation as well isolation and lack of identity are the elements that could delay the entry into the retirement home.

In this research, we would like to focus on persons with major neurodegenerative disorders who would like to stay at home as long as possible. These disorders are more and more present with aging of population, which lead us to reflect on the future home 4.0 by permitting residents to live their activities of daily living (ADL).

New technologies and connected objects could be the potential solutions for designing the future home. During this study, we will identify the contradictions that could be existed among different solution's concepts based on functional criteria. These criteria are proposed in parameters according to the TRIZ method in order to propose principles of solution's concepts.
\end{abstract}

\section{Keywords.}

Usage, Multi-user, Contradiction, Design, Neurodegenerative disorders.

\section{Introduction}

In the next ten years, the sociological face of French society will have changed because of ageing the population. People over 60 years old will represent a third of the population in 2040. People will live longer, but, with the emergence of new diseases, such as major neurodegenerative disorders, such as Alzheimer, Parkinson, Lewy bodies Corps, dementia vascular... [1], these pathologies differ from others as mobility difficulties or other physical disabilities.

The Neurological pathologies will have an effect on people staying at home, on their level of autonomy, as well, on their ability to continue the activities of daily living [2]. People affected by this pathology have also an impact on the healthcare assistant, that make him/her exhausted, tired and depressed. 
The aim of this research is how to care these fragile people at home by identifying the contradictions and complementarity between their needs and their hops. Hence, the interest of this research is to adapt the home to this new situation. We will focus in this research on the future home 4.0 [3], particularly on the needs and functional study.

\section{Research approach}

Our approach in this research will be using a mix of the methods SWOT, User Experience and functional analysis. Each method will be satisfied and answered to the needs of our case.

The SWOT (Strengths, Weaknesses, Opportunities and Threats) method permit us to analyze and diagnostic the current situation of resident by Strengths, Weaknesses, Opportunities and Threats. The factors which are important role in her/his environment both interior and exterior of home. The objective of user experience is multiple. It can be user experience for a resident life style at home, healthcare assistance, nurses or other person who help the resident. We will discuss for all type of users in this paper. For example, the resident need to participate and to perform their daily activities.

She/he should use specific product, system, or services immediately in an easier way in our case. This products, system or service must be ergonomic and applicable immediately. The functional analysis method allows us to do study of needs for the new home 4.0. [4], that we used it based on TRIZ approaches. Figure 1 show the relations and needs in our methodological approach.

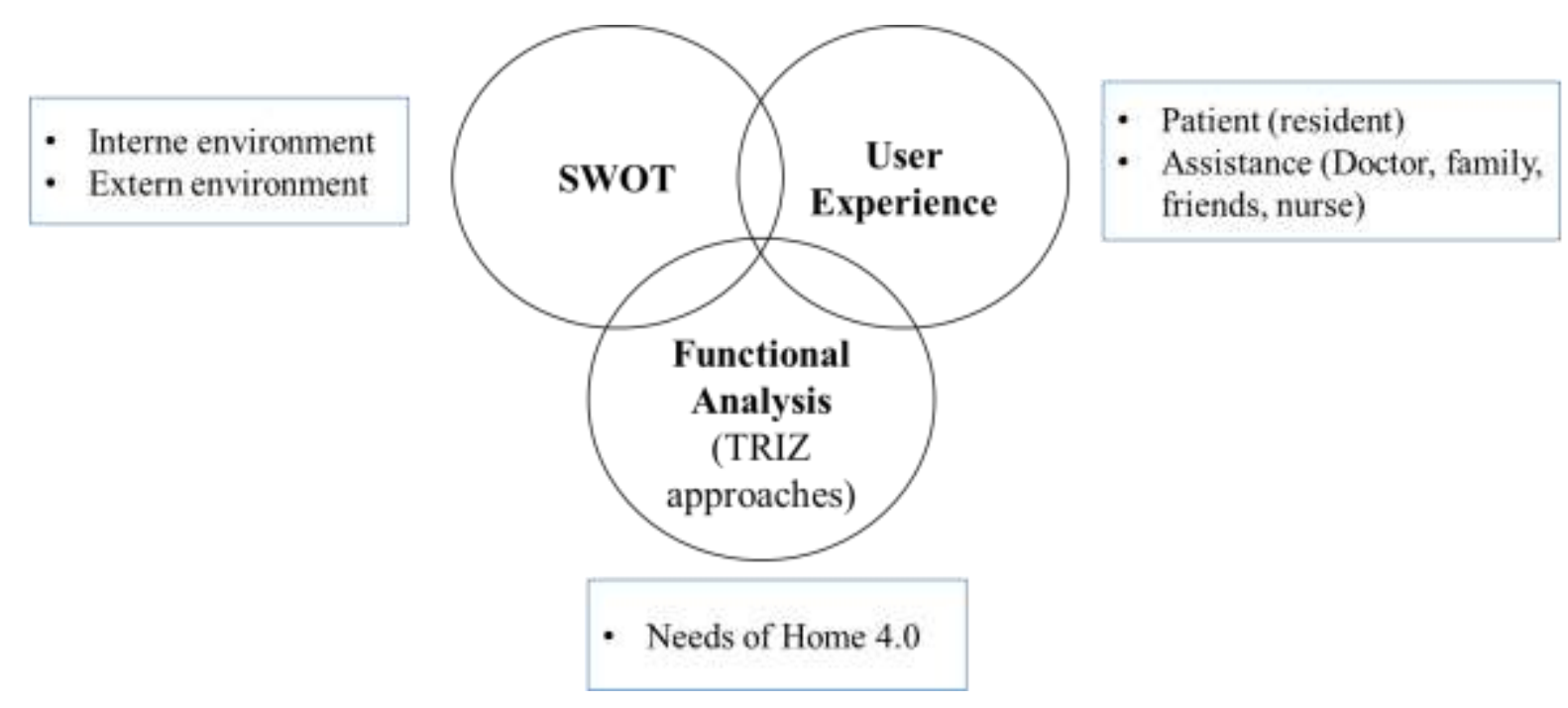

Fig1. Our methodological approach 


\section{Home 4.0}

\subsection{Current situation}

In these days, the old French people wish to stay at home as long as possible. They prefer to delay the time of moving to retirement home, whether alone or rally around. Therefore, their family at home tries to innovate or have a long-term planning. They start to modify their house or apartment, such as rearranging the bathroom (on a level) or removing the access of rooms on the floor and preparing house on a level. Sometimes, they sell their house and by another. Therefore, they try to change their house to have more functional and comfortable for their old person. That means they anticipate rearranging the house depending disabilities of their old person. In the framework of this work, it is necessary to demonstrate the way of preparing home for the old person in order that he/she could stay at home as long as possible. It is about replacing the user, the future resident, at home as part of his/her needs and imagine the future home to be functional [5]. The future resident of home 4.0 could be different kind of users at home and the user or resident in this paper is mainly the old person how will live in home4.0. The other users could be presented at Home 4.0 such as: a healthcare assistant, nurse, family doctor or neighbors.

\subsection{The analyze of current home based on SWOT method}

At first, we propose to perform analysis of strengths and weakness for the current home in order to reflect on the future home 4.0. These analyses are based on SWOT method. This assessment permits us to provide a better understanding of the resident's interests at home, about his/her strengths and limits and possibility to improve the house (table 1).

\begin{tabular}{|c|c|}
\hline Strengths & Weaknesses \\
\hline $\begin{array}{l}\text { - Continue to have her/his habits and } \\
\text { activities at home } \\
\text { - Social bond with friends and neighbors } \\
\text { - } \text { The resident is not disoriented } \\
\text { - The budget is lower regarding the place } \\
\text { - Keep his mark on the surrounding, } \\
\text { neighbors, friends. } \\
\text { - feel more comfortable in the apartment } \\
\text { - The resident has self-confidence thanks } \\
\text { to this autonomy } \\
\text { - The resident could be always autono- } \\
\text { mous }\end{array}$ & $\begin{array}{l}\text { - The resident is alone with an evolving } \\
\text { pathology and with security risks } \\
\text { - Less monitoring } \\
\text { - Monitoring is not continuous } \\
\text { - Isolation of the resident, anonymity } \\
\text { - Non-regularity of needs } \\
\text { - any alerts in case of problems (fall down, } \\
\quad \text { slips, or movements ...) }\end{array}$ \\
\hline Opportunities & Threats \\
\hline
\end{tabular}




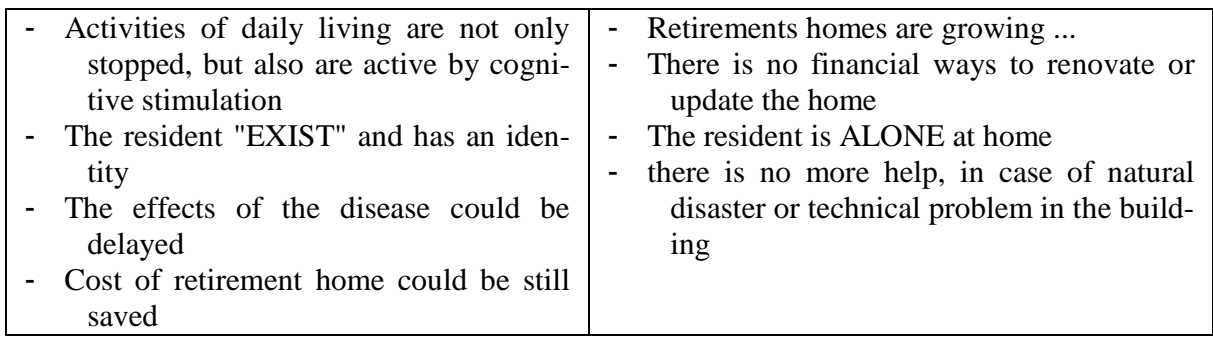

Table.1. Study of the current home from the SWOT grid

In SWOT method, Strengths, Weaknesses are about intern factors, in our case it is about the situation of resident at home. The Opportunities and Threats are about extern factor, so in our case exterior of resident's home, means environment factors which could have an effect on the resident.

\subsection{The future home 4.0}

The connected and automated objects will have main place in this new future home 4.0. The objective is not setting up a hyper connected environment, but to assess the autonomy of the resident and evaluate her/his needs as an actor for his/her daily activities [6]. The renovated home will not only be a place to live her/his end of life in a way just "cared", but also, to be able as an actor to manage his/her handicaps and degree of autonomy. Hence, the home should not just be a place to live, but, a place where cognitive stimulation or other forms of stimulation are part of daily activities.

The type of home that we would like to design for the resident consist in being able to stimulate activities of daily living (ADL) safely, in a way that the social bond is as well safeguard.

Actually, in this case, there is the expertise of user instead of customer's needs. That means, the resident of the home is no more a customer who expects a service for a payment, but, an expert user who knows his/her pathology through the healthcare assistant. The healthcare assistant changes his role; she/he has to no more suffer the effects of disease, but must anticipate its effects. The medical body does not only provide the care or a specific service, but also, they must accompany the resident in his activities of daily life [7-8].

\section{User Experience UX}

\subsection{Definition of User Experience UX}

In recent years, some authors have focused on the user experience, called "user experience (UX)" [9-10]. This refers to the experience of a person using a specific product, system or service. It's about making a product, a system easy to use, under- 
standable immediately, ergonomic, logical, by integrating user experience into product design [11-12].

In this sense, design studies must be able to identify or consider different users according to the product's life cycle. It is not rare to note that the product in operation phase has several users. Designers must transform customer's/user's requirements into product performance. It should be noted that the requirements of the customer are not the same as those of user (it is the first level of contradiction). Subsequently, the designers will have to prioritize these users, in order to better understand the features of the product according to the type of user. The functional analysis makes it possible to answer it.

\subsection{Different users UX}

Analyzing a need means translating the product into "Customer specifications" and/or "User's specifications". The "client as user" reasons in solutions rather than needs. When there are multiple users, we talk about multi-users. The functional analysis approach is a response to this search for users' needs. In our study for designing the future home, we are looking for different types of users as showed in table 2.

\begin{tabular}{|c|c|c|c|}
\hline User type & $\left(\mathbf{U} \mathbf{X}_{\mathbf{i}}\right)$ & User-Experience & Activities \\
\hline \multirow{3}{*}{$\begin{array}{l}\text { Resident at home } \\
\text { (different users) }\end{array}$} & $\mathrm{UX}_{1}$ & cooker & $\begin{array}{l}\text { Culinary activities, wash- } \\
\text { ings dishes, setting the table }\end{array}$ \\
\hline & $\mathrm{UX}_{2}$ & Gardener & $\begin{array}{c}\ldots \\
\text { Gardening, Planting, Wa- } \\
\text { tering... }\end{array}$ \\
\hline & $\mathrm{UX}_{3}$ & Cleaning agent & $\begin{array}{l}\text { Setting the table, clearing } \\
\text { the table, washing dishes ... }\end{array}$ \\
\hline $\begin{array}{l}\text { Healthcare assis- } \\
\text { tant }\end{array}$ & $\mathrm{UX}_{4}$ & Nursing & Toilet, hygiene... \\
\hline $\begin{array}{l}\text { Nurse and/or doc- } \\
\text { tor }\end{array}$ & $\mathrm{UX}_{5}$ & $\begin{array}{l}\text { Medical follow-up, } \\
\text { taking medicine }\end{array}$ & $\begin{array}{l}\text { Manage medicine, per- } \\
\text { form care }\end{array}$ \\
\hline $\begin{array}{l}\text { Neighbors and/or } \\
\text { Friends }\end{array}$ & $\mathrm{UX}_{6}$ & $\begin{array}{l}\text { Conviviality, social } \\
\text { bond, }\end{array}$ & $\begin{array}{l}\text { Sharing moments, tea, } \\
\text { outing... }\end{array}$ \\
\hline $\begin{array}{l}\text { Relationship, fami- } \\
\text { ly }\end{array}$ & $\mathrm{UX}_{7}$ & $\begin{array}{l}\text { Legal guardian, } \\
\text { guardianship ... }\end{array}$ & $\begin{array}{l}\text { Guarantor against institu- } \\
\text { tions }\end{array}$ \\
\hline Care staff & $\mathrm{UX}_{8}$ & $\begin{array}{l}\text { Speech therapist, } \\
\text { Physiotherapist ... }\end{array}$ & $\begin{array}{c}\text { Bridging or stimulating } \\
\text { the resident's lack of autono- } \\
\text { my }\end{array}$ \\
\hline
\end{tabular}

Table 2. The different users at home.

\section{Functional analysis for home 4.0}

\subsection{Study of Needs}

A study of need is required in order to know exactly the needs for this new home 4.0. We propose to use the tools of study needs for functional analysis proposed by 
the firm APTE. There are some questions raise in order to define the goal or objective of this future home 4.0.

- Who does it help?

- What is used for?

- Who is it acting on?

- What does it work on?

At last, for what purpose or objective? We present in table 3 a synthetic result of study of needs for future home 4.0 by using the tool of cabinet APTE.

\begin{tabular}{|c|c|}
\hline Who does it help? & People with major neurodegenerative disorders (MND) \\
\hline What is used for? & Make their life easy and safe \\
\hline Who is it acting on? & Multi-user (patient, caregiver, etc.) \\
\hline What does it work on? & Daily life activities' simulation \\
\hline $\begin{array}{c}\text { For what purpose or ob- } \\
\text { jective? }\end{array}$ & $\begin{array}{c}\text { Allow people with MND to stay in their adapted home (future } \\
\text { 4.0) to their pathology as long as possible }\end{array}$ \\
\hline $\begin{array}{c}\text { Why this need exists? } \\
\text { (purpose, reason) }\end{array}$ & $\begin{array}{c}\text { Many people will be getting old with this pathology and wish to } \\
\text { stay at home as long as possible. The retirement homes are } \\
\text { limited and do not completely respond to this new pathology }\end{array}$ \\
\hline $\begin{array}{c}\text { What could make it disap- } \\
\text { pear? or evolve it? }\end{array}$ & $\begin{array}{c}\text { A remedy, medicine ... cure these pathologies of memory dis- } \\
\text { orders }\end{array}$ \\
\hline $\begin{array}{c}\text { What is the risk of disap- } \\
\text { pear? }\end{array}$ & $\begin{array}{c}\text { Nowadays, there is no any positive sign that appears as a solu- } \\
\text { tion to fight against these pathologies }\end{array}$ \\
\hline
\end{tabular}

Table 3. Study of the need for the future home 4.0

\subsection{Functional analysis}

We made our analysis form two levels: outside environment search and Service and constraints functions. The results of our analysis from outside environment search is presented in table 4.

\begin{tabular}{|l|l|l|}
\hline Mi & \multicolumn{1}{|c|}{ Type of outside environment } & \multicolumn{1}{|c|}{ Description of outside environment } \\
\hline$M_{1}$ & Kitchen equipment & Set of utensils for cooking ... \\
$\mathrm{M}_{2}$ & Gardening equipment & Bins, flowerpots, utensils, watering can, seeds ... \\
$\mathrm{M}_{3}$ & Mobility system & Staircase, walker, wheelchair, cane \\
$\mathrm{M}_{4}$ & Home resident & Person with MND, early stages (pathology) \\
$\mathrm{M}_{5}$ & Help team and accompanied $*$ & Healthcare assistant, Living Assistant Gerontol- \\
& & ogy \\
\hline $\mathrm{M}_{6}$ & Security ways & Alarm, keys, Digi code... \\
\hline $\mathrm{M}_{7}$ & Nurse, doctor, parents ... & Medical corps specialized in home care \\
$\mathrm{M}_{8}$ & Speech therapist, Kenseisha. $* *$ & Specialists in effects of pathology \\
$\mathrm{M}_{9}$ & Hygiene equipment, maintenance & Sponge, broom, washing machine, brush, prod- \\
$\mathrm{M}_{10}$ & Entertainment system & ucts \\
& & TV, games, books, armchair \\
\hline
\end{tabular}

* accompaniment (Healthcare assistant, Living Assistant ...)

**physiotherapist 
Table 4. outside environment search

In Service functions and constraints functions levels, the results are presented in the table 5:

\begin{tabular}{|c|c|c|c|c|}
\hline $\mathbf{F}_{\mathbf{i}}$ & Description of functions & Criteria $C_{j}$ & Level $\mathbf{N}_{\mathbf{k}}$ & $\begin{array}{l}\text { Flex. } \\
\text { Fl. }\end{array}$ \\
\hline$F_{1}$ & $\begin{array}{l}\text { The home } 4.0 \text { must allow resident to be } \\
\text { mobile thanks to the mobility system }\end{array}$ & $\begin{array}{c}\text { Mobility } \\
\text { Type of material }\end{array}$ & $\begin{array}{l}100 \% \\
\text { Base }\end{array}$ & $\mathrm{Fl} .2$ \\
\hline $\mathbf{F}_{2}$ & $\begin{array}{l}\text { The home } 4.0 \text { must allow resident to dispose } \\
\text { kitchen equipment for doing culinary activi- } \\
\text { ties safely }\end{array}$ & $\begin{array}{l}\text { Type of material } \\
\text { Type of activities }\end{array}$ & Autonomes & $\mathrm{Fl} .3$ \\
\hline $\mathbf{F}_{3}$ & $\begin{array}{l}\text { The home } 4.0 \text { must allow resident to wel- } \\
\text { come help team such as, doctor, nurse, } \\
\text { physiotherapist, neighbors, parents ... in } \\
\text { good conditions. }\end{array}$ & $\begin{array}{c}\text { Type of help } \\
\text { Type of reception }\end{array}$ & $\begin{array}{l}\text { Pathology } \\
\text { Access } \\
\text { Intervention }\end{array}$ & $\mathrm{Fl} .3$ \\
\hline $\mathbf{F}_{4}$ & $\begin{array}{l}\text { The home } 4.0 \text { must allow resident to practice } \\
\text { gardening activities safely }\end{array}$ & $\begin{array}{l}\text { Type of activity } \\
\text { Type of security }\end{array}$ & $\begin{array}{l}\text { Autonomous } \\
100 \%\end{array}$ & $\mathrm{Fl} .3$ \\
\hline $\mathbf{F}_{5}$ & $\begin{array}{l}\text { The home } 4.0 \text { must integrate home security } \\
\text { systems of resident }\end{array}$ & $\begin{array}{l}\text { systems } \\
\text { Level }\end{array}$ & $100 \%$ & Fl.1 \\
\hline F $_{6}$ & $\begin{array}{l}\text { Home } 4.0 \text { must be adapted to receive health } \\
\text { personnel in order to provide personalized } \\
\text { care to resident }\end{array}$ & $\begin{array}{l}\text { Type of access } \\
\text { Type of care }\end{array}$ & $\begin{array}{l}\text { Free } \\
\text { Autonomous }\end{array}$ & Fl.1 \\
\hline $\mathbf{F}_{7}$ & $\begin{array}{l}\text { Home } 4.0 \text { must allow resident to continue } \\
\text { the maintenance and hygiene activities of } \\
\text { her/his home }\end{array}$ & $\begin{array}{l}\text { Type of activities } \\
\text { Maintenance level }\end{array}$ & $\begin{array}{l}\text { Phase } 1 \text { to } 5 \\
\text { (illness) }\end{array}$ & Fl.3 \\
\hline F8 & $\begin{array}{l}\text { Home } 4.0 \text { must have an entertainment } \\
\text { system for the resident based on his degree } \\
\text { of independence }\end{array}$ & $\begin{array}{l}\text { Type of autonomy } \\
\text { Entertainment type }\end{array}$ & $\begin{array}{l}\text { Phase } 1 \text { to } 5 \\
\text { (according } \\
\text { autonomous) }\end{array}$ & Fl.3 \\
\hline
\end{tabular}

Table 5. Service functions' list or future home constraints

\subsection{Interaction of functional criteria}

In the table 6 , we privilege the functions and criteria related to safety according to the different users.

\begin{tabular}{|c|c|c|c|}
\hline Functions & Participant & Criteria & $\mathbf{C}_{\mathbf{i}}$ \\
\hline $\begin{array}{l}\mathrm{F}_{1} \text { Mobility Assis- } \\
\text { tance }\end{array}$ & Resident (without activity) & $\begin{array}{l}\text { Degree of autonomy and } \\
\text { Walking equipment }\end{array}$ & $\mathrm{C}_{1}$ \\
\hline$F_{2}$ safety & Resident (without activity) & Fonct. degree of Autonomy & $\mathrm{C}_{2}$ \\
\hline \multirow{4}{*}{$\begin{array}{c}\mathrm{F}_{3} \text { Reception of health } \\
\text { staff, friends, } \\
\text { healthcare assistants, } \\
\text { parents }\end{array}$} & Healthcare assistant, helper & Resident Hygiene Access & $\mathrm{C}_{3}$ \\
\hline & $\begin{array}{l}\text { Physiotherapist, speech } \\
\text { therapist }\end{array}$ & Adequate equipment, local, & $\mathrm{C}_{4}$ \\
\hline & Doctor, Nurse & Access, secure medicine ... & $\mathrm{C}_{5}$ \\
\hline & Friends, parents & Access, service, conviviality & $\mathrm{C}_{6}$ \\
\hline \multirow{2}{*}{$\mathrm{F}_{2}$ Cooking activities } & Resident & Dexterity, security & $\mathrm{C}_{7}$ \\
\hline & Assistant & Memory, procedure ... & $\mathrm{C}_{8}$ \\
\hline $\mathrm{F}_{4}$ Garden activities & Resident & Dexterity, time ... & $\mathrm{C}_{9}$ \\
\hline
\end{tabular}




\begin{tabular}{|c|l|l|l|}
\hline & & Products choice & $\mathrm{C}_{10}$ \\
\hline \multirow{2}{*}{$\begin{array}{c}\mathrm{F}_{7} \text { Maintenance activ- } \\
\text { ities }\end{array}$} & Resident & Products safety & $\mathrm{C}_{11}$ \\
\cline { 2 - 4 } & & handling & $\mathrm{C}_{12}$ \\
\hline \multirow{2}{*}{$\begin{array}{c}\text { F }_{8} \text { Relaxation activi- } \\
\text { ties }\end{array}$} & Resident & Comfort & $\mathrm{C}_{13}$ \\
\cline { 2 - 4 } & Resident & Freedom of movement & $\mathrm{C}_{14}$ \\
\cline { 2 - 4 } & & Motivation of activity & $\mathrm{C}_{15}$ \\
\hline
\end{tabular}

Table 6. Criteria's Functions and safety according to the type of user

\section{Discussion}

Based on different criteria, we will seek the opposition criteria or complementary criteria, in order to find a solution, as presented in table 7. For examples, we present criteria that are complementary or in opposition one to another and we propose recommendations in terms of solutions. These recommendations can have a positive impact on the choice of solutions. For exemple :

From the criteria resulting from the functional analysis, the question is converting them into parameters in order to emerge contradictions among them, and find the principles of solutions' Concepts.

The criterion C2 (Function F2) is "Degree of autonomy". The degree of autonomy is specified: either total or less use of right hand or left hand (depends on the person is right-handed or left-handed). The criterion $\mathrm{C} 7$ is "level of dexterity" of resident to carry out certain cooking activities that require the use of both hands. A contradiction is:

- Either, to increase the degree of autonomy for criterion $\mathrm{C} 2$ by asking resident to work in groups of two people,

- Or, to decrease the C7 criterion by looking for an ergonomic device that comes to replace the deficient hand.

\begin{tabular}{|c|l|}
\hline $\begin{array}{c}\text { Opposition crite- } \\
\text { ria }\end{array}$ & \multicolumn{1}{c|}{ Comments } \\
\hline $\mathrm{C}_{2}-\mathrm{C}_{7}$ & $\begin{array}{l}\text { Secure resident during cooking activities (knives, electrics...). } \\
\text { Secure devices for people with MND. } \\
\text { Make the resident autonomous with a minimum of safety whereas the } \\
\text { safety in the kitchen must be increased }\end{array}$ \\
\hline $\mathrm{C}_{7}-\mathrm{C}_{11}$ & $\begin{array}{l}\text { Safety systems for cooking as well, maintaining furniture, there are not } \\
\text { the same level of protection on the floors or other parts of home. } \\
\text { The kitchen must be secured regarding the movement of residents, } \\
\text { while, it is forbidden for maintenance }\end{array}$ \\
\hline $\begin{array}{c}\text { Complementary } \\
\text { criteria }\end{array}$ & \multicolumn{1}{c|}{ Comments } \\
\hline $\mathrm{C}_{9}-\mathrm{C}_{7}$ & $\begin{array}{l}\text { About these two activities (garden and kitchen), we use cutting or } \\
\text { slicing objects... in the same manipulations. }\end{array}$ \\
\hline
\end{tabular}




\begin{tabular}{|c|l|}
\hline & $\begin{array}{l}\text { Only the base changes. Electrical tools are also dangerous and must be } \\
\text { secured. }\end{array}$ \\
\hline $\mathrm{C}_{11}-\mathrm{C}_{2}$ & $\begin{array}{l}\text { In general, the resident must be safe in his basic daily activities such as } \\
\text { arrangement and storage activities, maintenance ... } \\
\text { The use of dangerous products must be controlled, monitored ... both in } \\
\text { terms of arrangement and manipulation level. }\end{array}$ \\
\hline $\mathrm{C}_{2}-\mathrm{C}_{13}$ et $\mathrm{C}_{14}$ & $\begin{array}{l}\text { safety depends on the disability of the resident and his pathology. } \\
\text { This security is done in agreement with the resident without risky ac- } \\
\text { tivities (cooking, gardening, maintenance ...) }\end{array}$ \\
\hline
\end{tabular}

Table 7. the opposition criteria or complementary criteria

\section{Conclusion}

In this paper, we wanted to discuss innovative research support such as the study of the future home in the medico-social sector. This support is topical because of the aging of the population and the response that society will have to provide.

In answer our research problem we used a mix of three methods SWOT, User experience and functional analysis.It is this framework we also used the functional analysis and the beginning of the TRIZ approach. This work is a beginning of reflection and deserves to be followed-up in subsequent studies. In the future work we work on how to transform the functional criteria into TRIZ parameters in order to look for principles of solutions.

\section{$8 \quad$ References}

1. Fior S, Julien M, Dorenlot P, Lallemand D. L'aide aux aidants : approche internationale (Vivre avec la maladie d'Alzheimer). Fondation Médéric Alzheimer (Paris) Edition, 2003.

2. Aguirre E, Hoare Z, Spector A, Woods RT, Orrell M., The effects of cognitive stimulation therapy (CST) programme for people with dementia on family caregiver'health. $B M C$ Geriatr $2014 ; 14: 31$.

3. Thomas P, Ingrand P, Lalloue F, Hazif-Thomas C, Billon R, Vieban F, et al. Reasons of informal caregivers for institutionalizing dementia patients previously living at home: the Pixel study. Int J Geriatr Psychiatry 2004 ; 19 : 127-35.

4. Tsai, T-H, Zhang, K-L., Implementation of intelligent home appliances based on IOT, IEEE, APCCAS, pp. 146-148, 2016.

5. Abramiuc, B, and all, Home video monitoring system for neurodegenerative diseases based on commercial HD cameras, IEEE 5th International Conference on Consumer Electronics Berlin (ICCE-Berlin), pp. 489-492, 2015.

6. Rossey, J., and all, Wi-Fi helping out Bluetooth Smart for an improved home automation user experience, IEEE, 2016.

7. Darses, F., Wolff M., How do designers represent to themselves the users' needs?, Applied Ergonomics 37(6) : 757-764, (2006). 
8. Obradovich, J. H., Woods D. D., Users as designers: how people cope with poor HCI design in computer-based medical devices. Human Factors: The Journal of the Human Factors and Ergonomics Society 38(4): 574-592, (1996).

9. Sun X, Houssin R., Renaud J., Gardoni M., Integrating user information into design process to solve contradictions in product usage, Procedia CIRP 39 (2016) 166 - 172. (2016).

10. Sun, X., Houssin, R., Renaud, J., M. Gardoni, "Towards a use information integration framework in the early product design phase function-task-behaviour." International Journal of Production Research, ISSN: 1366-588X, (2018).

11. Folcher, V., Appropriating artifacts as instruments: when design-for-use meets design-inuse, Interacting with Computers, 15(5), 647-663, (2003).

12. Gero, J. S., Kannengiesser U., The situated function-behaviour-structure framework, Design Studies $25: 373-391,(2004)$. 